\title{
Preserving Local Literary Community: Literary Planning and Policy as a Cultural Strategy in Indonesia
}

\author{
Nadya Afdholy ${ }^{\mathrm{a}, 1^{*}}$, Anas Ahmadib,2, Ghanesya Hari Murtic,3 \\ a Universitas Airlangga, Jl. Dharmawangsa Dalam, Airlangga, Gubeng, Surabaya, 60286, Indonesia \\ b Universitas Negeri Surabaya, Jl. Lidah Wetan, Lakarsantri, Surabaya, 60213, Indonesia \\ c Politeknik Negeri Jember, Jl. Mastrip No. 64, Sumbersari, Jember, 68101, Indonesia \\ ${ }^{1}$ nadya-a-08@fib.unair.ac.id; ${ }^{2}$ anasahmadi@unesa.ac.id; ${ }^{3}$ ghanesya@polije.ac.id \\ * Corresponding Author
}

\begin{tabular}{|c|c|}
\hline INFO ARTIKEL & ABSTRAK \\
\hline $\begin{array}{l}\text { Sejarah Artikel: } \\
\text { Diterima: } 5 \text { Oktober } \\
2020 \\
\text { Direvisi: } 31 \text { Oktober } \\
2020 \\
\text { Disetujui: } 12 \text { November } \\
2020 \\
\text { Tersedia Daring: } 16 \\
\text { November } 2020 \\
\text { Kata Kunci: } \\
\text { komunitas } \\
\text { sastra } \\
\text { perencanaan } \\
\text { revitalisasi } \\
\text { strategi }\end{array}$ & $\begin{array}{l}\text { Perkembangan komunitas sastra di Indonesia yang tersebar di setiap } \\
\text { daerah dari Sabang sampai Merauke kurang mendapat perhatian dari } \\
\text { pemerintah. Komunitas sastra di daerah dapat terus produktif } \\
\text { menghasilkan karya tetapi kesulitan untuk tetap bertahan. Artikel ini } \\
\text { bertujuan memberi rekomendasi terkait perencanaan dan kebijakan guna } \\
\text { menanggulangi berbagai macam problem sastra Indonesia, khususnya } \\
\text { problem di kancah internasional, potensi-potensi daerah, sayembara } \\
\text { penulisan sastra, ataupun dokumentasi historiografis perkembangan } \\
\text { karya sastra Indonesia. Komunitas sastra seharusnya dapat diberdayakan } \\
\text { secara optimal melalui perencanaan dan kebijakan makro guna } \\
\text { merevitalisasi komunitas sastra di setiap daerah. Penulis } \\
\text { merekomendasikan strategi untuk merevitalisasi komunitas sastra di } \\
\text { daerah, yakni membentuk lembaga khusus dari pemerintah yang } \\
\text { independen, mencatat dan mengarsipkan perkembangan komunitas } \\
\text { sastra dari tahun ke tahun, dan menyisihkan dana hibah untuk komunitas } \\
\text { sastra di tiap daerah. Rekomendasi ini diharapkan dapat menanggulangi } \\
\text { problem sastra Indonesia di kancah internasional. }\end{array}$ \\
\hline & ABSTRACT \\
\hline $\begin{array}{l}\text { Keywords: } \\
\text { community } \\
\text { literary } \\
\text { planning } \\
\text { revitalization } \\
\text { strategy }\end{array}$ & $\begin{array}{l}\text { The development of literary communities in Indonesia which spread in } \\
\text { every region receive less attention from the government. Literary } \\
\text { communities can continue to productively produce works but struggle to } \\
\text { survive. This article aims to providing recommendations related to planning } \\
\text { and policy to overcome various kinds of Indonesian literary, especially } \\
\text { problems in international arena, regional potentials, literary contests, or } \\
\text { historiographic documentation of Indonesian literary works development. } \\
\text { Literary communities should be optimally empowered through macro } \\
\text { planning and policy to revitalize their self in each region. The author } \\
\text { recommends several strategies to revitalize local literary communities, } \\
\text { namely forming special institutions from independent governments, noting } \\
\text { and archiving the development of the literary community from year to year, } \\
\text { and setting aside grants for the literary community in each region. This } \\
\text { recommendation is expected to overcome the problem of Indonesian } \\
\text { literature in international arena. }\end{array}$ \\
\hline
\end{tabular}

(C) 2020 , Afdholy, Ahmadi, \& Murti This is an open access article under CC-BY license (c) (i) () 


\section{Introduction}

The literary community has grown widely in Indonesia, but it is not well documented. So far, the literary community has remained unorganized, spread throughout Indonesia from Sabang to Merauke, but its development has not been mapped. It is unknown the exact number of literary communities that are scattered in Indonesia and there are no institutions that are really serious about caring for the literary community. The problem is not on low or how high the literacy should develop. In fact, the literary community is the main place for the seeds of literature (Manuaba, 2019:328). The role of the state is very minimal for the development of literature in each region in Indonesia. During this time, the recorders of all the works of the literary community are ind ustry and publishers, not all of which can be easily questioned in detail.

In the context of literary planning in Indonesia, conceptually and practically, it is still less than optimal (Ahmadi, 2020). This is evident in the agenda of activities held by the Language Training and Development Center. Recognized or not, there are more activities in the linguistic context than literature. In this case, the activity is funded and implemented by the state. It indeed shows that literary planning in Indonesia is still inferior to language planning. Government care is more biased towards language than literature, so the language community looks more radiant than the literary community.

In 2015 Indonesia was the guest of honor at the Frankfurt Book Fair (FBF), German (Lingard, 2016:54). The Indonesian National Committee, chaired by Goenawan Mohamad, decided around 120 names of representatives from nine groups that had been curated by the book and translation committee appointed by the Ministry of Education and Culture, namely literary and fiction books, comics, children's books, nonfiction books, digital books, culinary cooks and figures, literacy activists, seminar speakers, and readers of works (Probo, 2015). Goenawan Mohammad is very selective in choosing whose work deserves to be displayed at the 2015 Frankfurt Book Fair (FBF).

Frankfurt Book Fair (FBF) provides an opportunity for Indonesian writers to translate their work (Rae, 2018:133). Dewi Lestari and Andrea Hirata are among the top 10 writers from Indonesia, including the names Pramoedya Ananta Toer, Mochtar Lubis, and WS. Rendra (Adji, 2018:107). Other well-known writers include Ahmad Tohari, Ayu Utami, Dewi Lestari, Eka Kurniawan, Laksmi Pamuntjak, Leila S. Chudori, Linda Christanty, and Seno Gumira Ajidarma (Probo, 2015). The participation of the Indonesian state in a prestigious event which was attended by hundreds of thousands of visitors throughout the world is an important step to introduce more books from Indonesia on the international scene.

The conditions of various literary communities in Indonesia requires serious attention because of their fluctuating existence (Manuaba, 2019:37). Departing from the absence of a good record of the literary communities and the list of works produced, Indonesia has become less than optimal in the international arena. Though many literary works that are published independently are no less interesting than the works of writers who are already established (legitimate) and populist industries. Works that are published independently have never been recorded as works that are poured and are not well documented, so they cannot be categorized as eligible to participate in the Frankfurt Book Fair (FBF).

The number of institutions to house the literary community is not specific because it still depends on the regional arts council which is fundedly tied to the respective regional finances. Unlike the language community, there are no institutions that specifically treat the literary community in 
every region in Indonesia. For disbursement of fund s each region was relatively different, between remote areas the funds tended to be less than industrial areas such as in Jakarta, as evidenced in Jakarta being able to hold a literary party Jakarta International Literary Festival (JILF) which was held August 20-24 at Taman Ismail Marzuki, Jakarta (Sari, 2019). The Jakarta International Literary Festival (JILF) is an international event attended by a number of writers from abroad.

There are no literary festivals in the area to be noted whose portions are balanced by those in Jakarta. The writing of literary works by literary communities in the regions is not well recorded. Historical writing and literary studies are still centered in Jakarta, while in the local mass media and local publishing escape (Budianta, 2009:38). Nationally, there is no equalization between one region and another, so all refer to Jakarta. The existence of the writing contest was most often held by the Jakarta Arts Council. The Jakarta Arts Council is an institution that is able to design the development of Indonesian culture because it is supported by the power of symbolic capital through agents who have legitimacy (Zurmailis \& Faruk, 2017:69). It is as if Jakarta is a barometer, whereas in other regions it is not well recorded.

This article aims to recommend planning and policy to overcome various kinds of problems in the future, especially problems in the international arena, regional potentials, literary contest, or historiographic documentation of the development of literary works because until now there is no historiography. Literary communities in Indonesia tend to have no recording, documentation, and treatment so that they are often not detected, not maintained, and even disappear, even though they are communities that need to be cared for, not only for the sake of culture but also as an international fighting force in the Nobel or world events such as the Frankfurt Book Fair (FBF) which is the author's deficit.

Of the cases found as mentioned in the background, policies and plans can be set at the macro level. Planning and policy at the macro level can be utilized in the development of a community (Kaplan, 2011:925). The role of government at the macro level to design large-scale planning must be measurable and have a clear shot, so that it is more targeted according to objectives. Macro planning is systematic by including specific actions planned and implemented in order to officially announce policies to obtain certain results (Kheng \& Baldauf Jr, 2011:937). Policies that are planned in earnest are manifested in the form of texts that define certain processes and expect results.

The policy made is a continuous turn around process which includes modification between text and actions as part of the ongoing implementation process (Kheng \& Baldauf Jr, 2011:937). Macro level planning also involves micro planning (Franker \& James, 2016:49). Micro planning is classified in the larger macro framework. Therefore, macro planning needs to be juxtaposed with personal policies and strategies by various actors at the micro level.

Literary planning that aims to revitalize community literature at the regional level must be fully supported by policy makers who then translate it into the form of laws, rules or laws followed by practices implemented by the government (Kheng \& Baldauf Jr, 2011:937). The government must take over and fully support the care of the literary community in the region because institutions such as the arts council that are scattered in each region are too general and not specific to literature, not to mention minimal funding in various sectors of the regional sector, so there need s to be a national literary body to treat the community. contemporary literary community in the area.

\section{Discussion}

Regional literature, local literature, and locality today are indeed the attention of the community of literary researchers (Ahmadi \& Yulianto, 2019). This shows the awareness of the community that locality and regionalism are very important. In addition to showing identity, the conceptualization of locality and 
regionalism is an effort to promote oneself on the international scene. Therefore, the revitalization of locality and regionalism, for example literature is very urgent.

Revitalization in the context of language and literary protection, more specifically literary revitalization is an effort to preserve and preserve sustainability, through development and coaching. Literary revitalization includes community-based literary revitalization, compiling materials and models of community-based literary revitalization, transferring and modifying literary works, and adaptation of literary works (Gloriani, 2017:5). Efforts to protect language and literature have been strengthened by Government Regulation Number 57 of 2014 (PP No. 57/2014) concerning the development, development and protection of language and literature, as well as the improvement of the function of Indonesian.

The problems that exist in a literary community cause the community is not sustainable and not profit oriented. The literary community has more attention to the development of the literary world (Muslimin, 2018:16). The literary community can continue to be creative and busy in the production of works and performances, but to sustain is very difficult and need to be regulated. Therefore, it is necessary to plan a national body that can be used as a manager for the literary communities in the region so that the works and performances of the literary community are maintained and can be well archived for circulation throughout the world. The hope, with a good managerial will all be more centered.

To overcome the problems in the literary community in the region, there needs to be a serious effort from the government to revitalize. Literature development cannot be carried out optimally without assistance and collaboration with various parties (Burhanudin \& Nuryatin, 2019:869). Therefore, revitalization can be done by involving the community, community, local government, and national bodies. All of them must work together well together so that they are more maximized in their development and empowerment. With the existence of a macro-level national board, there is a hope that literary communities in local region able to move on, and upload activities independently to the institution so that there will be a dynamic process, taking notes, as well as dissemination of good quality historiographic about potential and constraints in each region. To be more maximized in its empowerment, planning and policy are needed to overshadow the literary community in the region, including:

\subsection{Establish a Special Institution from an Independent Government}

The government must establish a special institution that is specifically devoted to caring for the literary community in the area tasked with caring for the sustainability of the literary community by providing facilities and reading parks that can be accessed by the public, so that the literary communities in the area will develop. Literary works in the regions are assumed to be unique both aesthetically and extra esthetically (Manuaba, 2016:168). If there is a centralized national board that takes care of the regional literary community, all the works of the literary communities will be well recorded. A special institution from the government is expected to be a truly independent institution and has a commissioner from a legitimate writer so that the division is clear, as at the Bourdieu level; bourgeois legitimacy, popular and specific. So, the need sof all types of literature will be fulfilled.

Special institutions from the government are expected to be unlike Balai Pustaka, which is capital. The Balai Pustaka Commissioner was not a literary person and at that time capitalists were increasingly driven by the state so that only certain novels could be published, such as the Sitti Nurbaya novel by Marah Rusli. Sitti Nurbaya was very monumental in the Balai Pustaka period (Rinaldi, 2016:155). Novels published in the Balai Pustaka period did not endanger the country. It might only endanger certain communities such as in the Minangkabau community, which many oppose the custom of matchmaking or the problem of tension between the young and old, but it does not endanger the state, instead it hopes that there will be liberation. The need for literary works, 
especially novels of that era was suited to the need sof the state namely to ignite the colonial spirit.

The polemic that occurred in the Balai Pustaka period was certainly different from the current polemic. Balai Pustaka in 1917 was used as a place to document literary works (Tatatantra, 2016:12). Balai Pustaka is in charge in spreading and taking care of all literary works in Indonesia, both community and personal. However, because Balai Pustaka was formed by power, as the result, controversial works such as stories about LGBT (Lesbian, Gay, Bisexual, and Transgender) will not be able to penetrate into Balai Pustaka. Works containing controversy were censored in such a way that was in line with the interests of the power at that time which also included literary politics. For now, times have changed. Institutions formed by the government must be able to accommodate all works, whether serious, popular, acrobatic, and dime, all must be accommod ated because all have their respective segments

\subsection{Taking Notes and Archiving the Development of Literary Community from Year to Year}

The large number of literary communities that have changed names or have disappeared without a trace indicate poor record keeping or perhaps the number of literary communities that have been deflated because they are not well maintained. The number of literary communities is relatively changing, can increase, and even something is missing. It turns out that these literary communities should be cared for by the art council, but because the constraints are funding (Sungkowati, 2010:102). Other constraints, the scope is not specific, even though the number of literary communities is very large and even the number exceeds the number of administrators of the arts council, it is necessary to consider proposals that there are certain national bodies to record the development of the literary community and its empowerment.

It is important to record the development of literary communities in this area so that the number of literary communities will continue to take place so that when there are international events such as the Frankfurt Book Fair (FBF) 2015 no longer only use the parameters of Jakarta as a good literary work. Jakarta is no longer the only literary and cultural mecca (Jabrohim, 2017:4). Literary communities in the area also have the opportunity to get a 'spotline'. Therefore, a national board must be formed to be specifically records, archives, and also empowers literary communities in the region. With the existence of a national body that is tackling or empowering the literary community in the area, it will be identified how many communities are deflated and what are the obstacles that cause the destruction of a community so that they cannot work anymore.

\subsection{Set aside Grants for the Literary Community in Each Region}

Besides taking notes and archiving, national board should give empowerment, provide funds to hold workshops, galleries, and various kinds. The issue of funding is one of the problems experienced by the literary community (Sungkowati, 2010:102). Grants must be prepared for literary communities in the area so that they can support the community and themselves or they will die, at least they must have their own production, such as making a writing competition for publication.

The literary community is not up to having an institution that houses or empowers because there are no special funds used to care. Most literary communities have weaknesses in funding (Manuaba, 2019:329). The literary community in the area has no militancy in struggling to defend its members. In the absence of available funds, the community cannot move around much, so the position is stagnant and only known in the area. The scope cannot possibly be large because no one is connecting. Even if it can be connected, the level is limited between communities. That culture is very difficult to change.

Funded communities such as the Salihara community, the Utan Kayu community and other well-funded communities will certainly develop and grow because they are internally cared for and well thought out. Salihara 
community has a modern management model that supports national and international partnerships (Manuaba, 2019:331). The people who are involved in the community also get paid, so when there is a big event, they are willing to work in totality. In contrast to the literary communities in the area that received less attention about funding and were not aware of the importance of funding, dreaming that funds would fall by themselves.

Another problem with the literary community is the relatively relaxed and nonserious character (Manuaba, 2019:166). They also have high self-titled, trapped with their own self, the recognition of writers, poets in certain areas, and already have legitimacy by the people in their area. Without realizing it, high selfishness and unwillingness to be open to other institutions/agencies will worsen the development of the literary community. By opening new platforms with old capital and style or hoping for new things with the old style, then the community will be very difficult to develop or it will die by itself.

Herfanda (in Sungkowati, 2010:103) said that the literary community is a number of people who voluntarily gather to appreciate and develop literature. Volunteering in this case can be a disadvantage, because it means the members of the community take turns. Community members who turn to the weaknesses of a community, they are free to go out and leave as they wish, only come when they are happy, when they need it, and when they love, but when they have a lot of work and other interests outside the community, they are neglected with his community. Such things happen because there is no funding to cover, there is no good coaching, and nothing makes residents feel comfortable so they have to fight for their community. It is natural that community dwellers not only think to support their community, but also think to support themselves.

\section{Conclusion}

The outbreak of the literary community in Indonesia tends to be undocumented and well-maintained so that the amount of growth and sustainability is often not detected.
Therefore, the development of the literary community in each region must be well documented so that its development can be mapped. With an institution that is really serious about caring for the literary community, Indonesia will have an international struggle both in the Nobel and world events such as the Frankfurt Book Fair (FBF). Literary communities in the regions are expected to be optimally empowered through macro planning and policy aimed at revitalizing the literary community in each region so that they are maintained and not extinct. The solution offered is to form a special institution from an independent government, note and archive the development of the literary community from year to year, and set aside grants for the literary community in each region. This recommendation is strategic in the hope of tackling the problems of Ind onesian literature in the future, especially in the international arena.

\section{References}

Adji, A. N. (2018). Revealing the ReTransformation of 9 Summers 10 Autumns. Paradigma, 8(1), 99-109.

Ahmad, A. (2019). Novel-Novel habiburrahman El Shirazy dalam Arena Produksi Kultural. Yogyakarta: Universtas Gadjah Mada.

Ahmadi, A. (2020). Perencanaan Bahasa dan Sastra Indonesia. Gresik: Graniti.

Ahmadi, A. \& Yulianto, B. (2019). Traditional Knowledge dalam Sastra Indonesia Perspektif Indigenous Studies. Gresik: Graniti.

Budianta, M. (2009). Keragaman Sastra dan Keindonesiaan sebuah Refleksi. Mabasan, 3(2), 35-47.

Burhanudin, M., \& Nuryatin, A. (2019). The Productivity of Literary Literacy Arena in Central Java. Proceeding of 
The International Conference on Literature: "Literature as a Source of Wisdom”, 1(1) (pp. 867-872). Banda Aceh: Universitas Syiah Kuala.

Franker, K., \& James, D. (2016). The Course Development Plan: Macro-Level Decisions and Micro-Level Processes. New Directions for Higher Education, 2016(173), 43-53.

Gloriani, Y. (2017). Konservasi dan Revitalisasi Bahasa sebagai Salah Satu Upaya Internasionalisasi Bahasa Indonesia. Fon: Jurnal Pendidikan Bahasa dan Sastra, 11(2), 1-11.

Jabrohim, J. (2017). Dari 'Diaspora Sastra' sampai Tema Kemanusiaan di dalam Antologi Puisi. Yogyakarta: Universitas Ahmad Dahlan.

Kaplan, R. B. (2011). Macro Language Planning. In E. Hinkel, Handbook of Research in Second Language Teaching and Learning Volume II (pp. 924-935). New York: Routledge.

Kheng, C. C., \& Baldauf Jr, R. B. (2011). Micro Language Planning. In E. Hinkel, Handbook of Research in Second Language Teaching and Learning Volume II (pp. 936-951). New York: Routledge.

Lingard, L. T. (2016). The Publishing Industry in Indonesia. Publishing Research Quarterly, 32(1), 54-57.

Manuaba, I. B. (2019). Indonesian Local Literature of Literary Organization Community Poduction as an Ethnicity Study and Local Wisdom in the Nationality and Globality Contest. Proceeding of The International Conference on Literature: "Literature as a Source Wisdom", 1(1) (pp. 327-333). Banda Aceh: Universitas Syiah Kuala.

Manuaba, I. B. (2019). Komunitas Sastra, Produksi Karya, dan Pembangunan
Karakter. Mozaik Humaniora, 19(1), 37-47.

Manuaba, I. B. (2019). Oral Communication in Literary Communities in East Java. Fifth PRASASTI International Seminar on Linguistics (PRASASTI 2019) (pp. 165-167). Jersey City: Atlantis Press.

Manuaba, I. B. (2016). Refleksi Kearifan Lokal dalam Sastra indonesia Karya Sastrawan Jawa Timur (Local Wisdom Reflection in indonesian Literature: Works by East Java Authors). Mozaik Humaniora, 16(2), 167-181.

Muslimin, M. F. (2018). Perkembangan Terkini Penelitian Sastra Akademik dan Non Akademik Menghadapi Revolusi Industri 4.0 (The Latest Outgrowth of Academic Literature Research and Non Academic Literature Research Facing Industrial Revolution 4.0). Kongres Bahasa indonesia, (pp. 1-17). Jakarta.

Probo, V. (2015). Seratusan Wajah Indonesia di Frankfurt Book Fair 2015. Retrieved from Cable News Network, Inc.:

https://www.cnnindonesia.com/hibur an/20150721185901-241-

67483/seratusan-wajah-ind onesia-difrankfurt-book-fair-2015

Rae, S. (2018). Sindhunata: An Indonesian Writer in his Context. Archipel: Études interdisciplinaires sur le monde insulindien, (95), 133-149.

Rinaldi, R. (2016). Warna Lokal Minangkabau dan Kesosialan Pengarang dalam Kumpulan Cerpen Penari dari Kuraitaji Karya Free Hearty. Puitika, 12(2), 149-159.

Sari, H. R. (2019). Pesta Sastra di Jakarta International Literary Festival 2019. Retrieved from Antara: https://www.antaranews.com/berita/ 
1028604/pesta-sastra-di-jakartainternational-literary-festival-2019

Sungkowati, Y. (2010). Memetakan

Komunitas Sastra Indonesia di Jawa

Timur (Mapping Indonesian Literary Community in East Java). Atavisme, 13(1), 100-116.

Tatatantra, A. B. (2016). Perancangan Pusat Penelitian dan Dokumentasi Sastra Jawa di Kota Madiun (Doctoral dissertation, Universitas Islam Negeri Maulana Malik Ibrahim).

Zurmailis, Z., \& Faruk, F. (2017). Doksa, Kekerasan Simbolik dan Habitus yang Ditumpangi dalam Konstruksi Kebudayaan di Dewan Kesenian Jakarta. Adabiyyat: Jurnal Bahasa dan Sastra, 1(1), 44-72. 